\title{
Teaching and Learning Classroom Action Research at a Distance in an Indonesian Urban Community
}

\author{
Sandra S. A., ${ }^{\mathrm{a},}{ }^{*}$ Durri Andriani, ${ }^{\mathrm{a}}$ Sunu Dwi Antoro, ${ }^{\mathrm{a}}$ Prayekti, ${ }^{\mathrm{a}}$ and Warsito ${ }^{\mathrm{a}}$ \\ andonesia Open University, Indonesia
}

\begin{abstract}
This action research project aims to understand whether teachers are mastering the knowledge and skills necessary to conduct classroom action research through two courses, Classroom Action Research (CAR) and Enhancing Teaching Professional Skills (PKP: Pemantapan Kemampuan Profesional), offered via distance education to Indonesian teachers and to identify areas for possible improvement of both courses. The research was conducted in two urban study centers located in the cities of Bogor and Tangerang in the Indonesian provinces of West Java and Banten. Data were collected via semi-structured interviews, classroom observations, questionnaires, and focus group discussions. All data were analyzed for patterns that might offer insight into the problems tutors and teacher-learners were facing as they worked through the Classroom Action Research (PTK: Penelitian Tindakan Kelas) module and tutorial. The research team from Indonesia Open University (UT: Universitas Terbuka) identified several problematic aspects of each course, including excessive lag time between the first and second courses, insufficient examples of model classroom action research projects, a lack of supervised practice of action research techniques, variability of tutorial quality, and a mismatch between course assessments and the content and purpose of the courses. While the findings of this study focus primarily on two distance courses offered by UT, they offer insight into the challenges of providing in-service teacher development via distance education in the Indonesian context.
\end{abstract}

\begin{abstract}
Abstrak
Penelitian tindakan kelas ini bertujuan (1) untuk mengetahui sejauh mana pemahaman dan kecakapan guru melakukan penelitian tindakan kelas, yang diajarkan melalui dua mata pelajaran, Penelitian Tindakan Kelas (PTK) dan Pemantapan Kemampuan Profesional (PKP), yang ditawarkan melalui program pendidikan jarak jauh untuk guru di Indonesia, dan (2) untuk mengidentifikasi hal-hal yang perlu diperbaiki dari kedua kelas tersebut. Penelitian dilakukan di dua pusat pembelajaran di kota Bogor dan kota Tangerang di Provinsi Jawa Barat dan Banten. Data diperoleh melalui wawancara semiterstruktur, observasi kelas, kuesioner, dan diskusi kelompok. Pola analisa ditujukan untuk mengidentifikasi kendala yang dihadapi tutor dan mahasiswaguru dalam proses tutorial dan modul PTK. Tim riset dari Universitas Terbuka Indonesia menemukan beberapa aspek permasalahan, meliputi interval waktu yang terlalu lama antara pertemuan kelas pertama dan kedua, kurangnya contoh model penelitan tindakan kelas, kurangnya bimbingan teknis penelitian tindakan, kualitas tutorial yang variatif, dan ketidaksesuaian antara tugas kuliah dengan tujuan dan materi pelajaran. Walaupun riset ini didasarkan pada dua program pendidikan jarak jauh oleh UT, namun hasil kajiannya dapat menjadi rujukan terkait dengan kendala penyelenggaran program pengembangan guru melalui program jarak jauh di Indonesia.
\end{abstract}

Key Words: Distance Learning, Classroom Action Research, Teacher Professional Skill

\section{Introduction}

Indonesia Open University (UT: Universitas Terbuka) is the only state university in Indonesia offering its programs entirely via

*Corresponding author. Address: Jalan Cabe Raya, Pondok

Cabe, Pamulang, Tangerang Selatan 15418, Banten, Indonesia.

Email: sandra@ut.ac.id. distance learning systems. Originally opened to accommodate the needs of a growing number of high school graduates who wanted to continue their education in college but could not be accommodated in face-to-face institutions, UT has grown into a mega-university serving more than 500,000 students through a network of 37 regional offices serving every province of Indonesia (UT 2001). Thus UT contributes to national development by expanding opportunities for anyone who is intellectually able to

(c) BY-NC-ND This work is licensed under a Creative Commons Attribution-Noncommercial-No Derivative Works 3.0 United States License. ISSN 2153-9669 (print) 2153-9677 (online) | doi: 10.5195/ehe.2011.47 | http://ehe.pitt.edu 
obtain university-level education, by providing higher education for those who are unable to continue their education in face-toface universities, and by developing academic and professional education programs that are tailored to the real needs of development (UT 2001).

Distance education allows UT students to learn without being restricted by time or place. They can learn while they work, and they can proceed through their course of study at a pace that meets their scheduling and financial needs. UT's approach encourages students to learn independently based on their own initiative and motivation. The success of this approach to independent learning requires self-discipline, a strong motivation to learn, and the ability to manage time efficiently. To support this process, UT provides self-learning materials that are designed to be selfinstructional, self-contained, and self-assessed through both printed media (modules) and non-print media (audio/video, computer/internet, radio and television broadcasts). UT also works with a number of state universities, private colleges, and other relevant agencies to develop course materials and to provide instructors of face-to-face tutorials convenient to the workplaces and homes of UT students.

UT has four faculties (colleges), one of which is the Faculty of Teacher Training and Education (FKIP) which provides in-service training for teachers, many of whom, particularly in rural areas of the country, currently hold diplomas equivalent to only two or three years of college-level study. Government legislation passed in 2005, however, requires all Indonesian teachers to hold a fouryear college degree by 2015 . This has placed considerable pressure on in-service teachers to earn a baccalaureate degree and has led to more than 400,000 practicing teachers throughout Indonesia enrolling in UT's Faculty of Education.

\section{Action Research}

Building critical skills in teaching is always very important. As Beth Brown $(2002,1)$ states "Engaging teachers in the process of raising questions and answering questions about how to improve the practice of teaching is essential." Through a process of learning and continuous self-development, teachers are expected to be able to actualize themselves in the task and reach the stage of inner satisfaction and self-confidence as an expert capable to work effectively in Indonesian schools. The Ministry of National Education and many teacher educators see the ability to conduct classroom action research as a skill essential to meeting such goals.

"Action research is a systematic approach to investigation that enables people to find effective solutions to problems they confront in their everyday lives" (Stringer 2007, 1). It is particularly useful as an approach to problems of practice; that is, problematic situations in which the investigator is concerned with more than simply understanding the phenomenon at hand but rather is interested in intervening in the phenomenon in order to direct it to some desired end. As such, action research is typically described as a cyclical process in which investigators proceed through multiple cycles of problem identification, data collection, analysis of data to a fuller understanding of the problem at hand and, eventually, to the testing of interventions which are in turn subjected to the same process of data collection, reflection, etc. until an adequate solution to the problem at hand is achieved (Kemmis and McTaggart 2000). It is widely used in a range of settings from pharmacy (Ngwerume and Themessl-Huber 2010) to social work (Hanson and Hanson 2010) to public health (Mendenhall, Harper, Stephenson, and Haas 2010), among others areas of inquiry.

Action research on the teaching-learning process in classrooms - classroom action research (CAR) - is a similar systematic process aimed at gathering information on teaching and learning problems in the classroom and working toward their solution. CAR is an on-going process of problem formulation, preparation of interventions, implementing interventions, observation and analysis of results, and reflection. Thus it often proceeds through several such cycles before a satisfactory solution is found. Peter Reason and Hilary Bradbury-Huang (2001) describe action research as an interactive inquiry process that balances problem solving actions implemented in a collaborative context with data-driven collaborative analysis or research to understand underlying causes enabling future predictions about personal and organizational change. In short, they argue that action research is learning by doing where a group of people identify a problem, do something to resolve it, see how successful their efforts were, and if not satisfied, try again. Action research is not simply oriented toward the immediate improvement of practice, however.

Action research ... aims to contribute both to the practical concerns of people in an immediate problematic situation and to further the goals of social science simultaneously. Thus, there is a dual commitment in action research to study a system and concurrently to collaborate with members of the system in changing it in what is together regarded as a desirable direction. Accomplishing this twin goal requires the active collaboration of researcher and client, and thus it stresses the importance of co-learning as a primary aspect of the research process. (Gilmore, Krantz, and Ramirez 1986, 161)

In order to help Indonesian teachers develop the capacity to improve their own instruction through classroom action research, 
UT offers two action research courses to students enrolled in its teacher training programs. The first, Classroom Action Research (PTK: Penelitian Tindakan Kelas), is offered in the sixth semester of teachers' program of study and focuses on the concepts and methods of action research. This course is intended to help teachers develop the ability to identify problems in their own classrooms and to find solutions via a systematic investigation into their causes and careful experimentation with responses to them that might lead to more effective teaching and learning. The second course, Enhancing Teaching Professional Skills (PKP: Pemantapan Kemampuan Profesional), is offered in the tenth semester of teachers' program of study and is intended to support the writing of a report on an actual classroom action research project. The gap between the two courses is intended to give teachers an opportunity to practice what they learned in the first course in their own classrooms.

Both courses were designed and developed at UT's main campus in Jakarta and are delivered throughout Indonesia via printed learning modules. Students' self-assessment of their progress through the course is provided through exercises and formative tests integrated into the module itself. These selfassessments require the learner to actively monitor and evaluate their own understanding of the course material. Learners, however, are not left entirely to their own devices. UT provides support in the form of tutorials - taught by local university lecturers - which give learners opportunities to work together and to receive face-to-face support if they need it. Final assessment of students' learning is measured via an objective test taken at the end of the course.

\section{Research Objectives and Questions}

In Indonesia, the completion of an undergraduate degree requires the student to carry out and write a report on a research project. Because the term "classroom action research" has been widely socialized among teachers and teacher trainers from earlier educational development efforts in the 1990s, it has become one of the most common approaches to completing this undergraduate thesis, known as the skripsi. For those in-service teachers who have enrolled in UT's teacher training program to comply with the new government requirement that all teachers earn a baccalaureate degree by 2015 , the skripsi is a significant hurdle. While the two action research classes offered by UT are intended to help these teachers over that hurdle, many still struggle with this final requirement. Therefore, in order to evaluate and, if necessary, revise the action research tutorials a team of lecturers from UT conducted an action research project in two of UT's tutorial centers designed to explore learners' perception of the tutorial, including the module itself, the tutorial process, the tutors and the relationship of the PTK tutorial to the PKP tutorial. The team wanted to better understand the challenges both learners and tutors encounter in preparing UT's teacher-learners to do classroom action research. The answers, we hope, will help improve the classroom action research curriculum offered by the FKIP at UT.

The problem of improving the quality of teaching and learning by teaching teachers to conduct action research is not as straightforward as we might imagine. There are a number of potential impediments, such as how well the concept of action research is understood by the teachers and how likely teachers are to apply action research in their own teaching. This is what the PTK tutorial is intended to accomplish. Mastering this material is essential to the teachers-learner's success is the second action research course, PKP. To better understand whether teachers are mastering the knowledge and skills necessary to conduct classroom action research, our inquiry was guided by the following questions:

1. What are the teachers' perceptions of the PTK course?

2. What are the tutors' perceptions of the PTK course?

3. What steps might be taken to improve the classroom action research curriculum at UT?

Since UT tutorials are necessarily developed by subject matter and curriculum development experts at its Jakarta campus, those developing the tutorials are widely separated temporally and geographically from the tutors and teacher-learners utilizing the tutorials. Answering these questions, therefore, is critical to understanding the effectiveness of the action research tutorials and guiding improvements in them as necessary.

\section{Research Sites and Methods}

The research team carried out this inquiry in two urban tutorial centers located in the cities of Tangerang and Bogor, both of which are in the region surrounding the Indonesian capitol, Jakarta. Both cities are heavily populated and suffer from many of the same problems that plague Indonesian cities: overcrowding, heavy traffic, etc. Life tends to be difficult and fast-paced. Teachers who work in these cities are, of course, affected by these conditions. Teachers in both cities, however, generally benefit from relatively good access - by Indonesian standards - to modern amenities such as utilities, adequate sanitation, modern housing, and public transportation. In both Bogor and Tangerang the close proximity of a large population to centers of business and industry enables residents to commute from home to work, thus diversifying employment opportunities and facilitating economic 
development. Bogor is a tourist city with a large number of natural and cultural attractions. This makes Bogor a natural location for selling arts and handicrafts. Tangerang, on the other hand, is the largest satellite urban center around Jakarta and the home of many industrial and manufacturing concerns. Many international corporations have plants in Tangerang city. As a result, a number of upper-class and middle-class communities - complete with their own shopping malls, private schools and convenience centershave grown up in Tangerang.

The research team selected urban research sites for several reasons. First, teaching posts in urban areas are generally considered more attractive by Indonesian teachers. Teachers in urban areas are also more likely to have somewhat easier access to universities and other professional development opportunities. Therefore, there is a possibility that teachers in urban areas may differ in significant ways from their rural counterparts. Also, the proximity to universities and availability of transportation increases the likelihood that the teacher-learners will have the support of competent tutors. If these assumptions are correct, then urban teachers' experience of the action research tutorials may be somewhat different from the experience of rural teachers and thus possibly require different adjustments in the tutorials.

The UT research team's investigation of the effectiveness of UT's action research tutorials was itself designed as an action research project. It was, therefore, intended to understand any problems teacher-learners were having in the tutorials in order to intervene and, hopefully, improve the tutorials so that they better met the needs of in-service teachers. Consistent with the conception of action research as a spiral of activities-problem formulation, data gathering, reflection, problem refinement, etc.the UT team conducted three complete cycles of data collection and analysis (Kemmis and McTaggart 2000; Stringer 2007). Data were collected using semi-structured interviews with teacherlearners and tutors, questionnaires distributed to teacher-learners, focus group discussions with teacher-learners, and observations of tutorial sessions. Table 1 below offers a summary of the data and data collection methods from each research site.

Table 1. Data Collection

\begin{tabular}{c|l|c|c|c|c|c}
\hline Cycle & Center & Observation & \multicolumn{2}{|c|}{ Interview } & Survey & \multirow{2}{*}{ Class } \\
\cline { 2 - 5 } & Tutor & Teacher & Teacher & FGD \\
\hline 1. & Bogor & 10 & 3 & 2 & - & - \\
\hline 2. & $\begin{array}{l}\text { Bogor and } \\
\text { Tangerang }\end{array}$ & 5 & 2 & 5 & 0 & 1 \\
\hline 3. & $\begin{array}{l}\text { Bogor and } \\
\text { Tangerang }\end{array}$ & 1 & 1 & 3 & 46 & 2 \\
\hline
\end{tabular}

Interviews and focus group discussions were recorded and transcribed. Observational data were recorded in field notes. All data were then analyzed holistically and then categorically in order to identify and trace patterns that might offer insight into the problems tutors and teacher-learners were facing as they worked through the PTK module and tutorial. After each cycle of data collection team members met to review and analyze the data gathered and formulate plans for further investigation. This process was repeated through three cycles, at which point the decrease in new observations and the increase in repeated observations led the team to conclude that they could reasonably conclude data collection.

\section{Findings}

The first cycle of data gathering and analysis revealed some positive aspects of the PTK tutorial along with several shortcomings. The tutors observed, for example, encouraged teachers to work in collaborative groups. When some groups were not ready for scheduled group presentations, the tutor gave the groups additional time to complete their presentations. The tutor also provided individual consultations on the results of teachers' observations. Teachers enrolled in the tutorial, however, offered a number of criticisms. The most common was the lack of opportunities to actually practice classroom action research during the course of the tutorial. One teacher reported, "Our tutor never asked us to conduct action research. We just learn how to do action research, but never implement it in our classroom" (Siti Interview, 20 September 2008). Another teacher said, "The tutor told us to remember the steps in conducting action research but never asked us to conduct one" (Agus Interview, 14 September 2008). The tutorial seemed to focus solely on concepts and theory rather than practice: "Yesterday I only learned theories . . . memorized the theories. I didn't really understand what it was all about. I only knew that it was good after I tried it out in the PKP course" (Eni Interview, 16 August 2009). The result of this was confusion about the circumstances in which the teachers were intended to use what they were learning. "I didn't even know that classroom action research can also be conducted outside this class. I was still confused about the meaning of class until just know when the tutor asked us to thing about conducting classroom action research in our classroom" (Siti Interview, 20 September 2008).

Tutors concurred with the teachers in their assessment of the theoretical bias of the PTK tutorial and the lack of opportunities to practice what they were learning about classroom action research. One tutor complained, "when they learn action research, they only learn the theories and they are not given the opportunity to apply the theories into real practices, such as designing, planning, formulating, and then applying what they have done" (Giman Interview, 16 August 2009). Another expressed the hope that "in 
the future the tutorials will cover the theories as well as how to implement the theories into real practices" (Budi Interview, 11 January 2009 ). Teachers and tutors also agreed on the lack of sufficient examples of classroom action research in the module as well as what some saw as a superficial treatment of the subject. "The module does not cover the deep discussion of the materials" (Tati Interview, 11 January 2009), one tutor said. This focus on theory at the expense of practice left teachers at a loss when they tried to use action research themselves. One teacher complained, "finding the problems is easy, but deciding which problems can be addressed through classroom action research was difficult" (Nurul Interview, 16 August 2009).

Mastering the material of the PTK tutorial is essential to students' future success in the PKP tutorial four semesters later. Teachers should be able to conduct classroom action research after participating in the PTK tutorial since they will be asked to write a report on a classroom action research project in the PKP tutorial, the final requirement for teachers to finish their baccalaureate degree in education. The research team tried, therefore, to understand tutors' perception of the relationship between the PTK and PKP modules. Their responses indicated that they understood the relationship and recognized that learning the theory, without actually applying it an actual classroom action research project, does not adequately prepare them for success in the PKP tutorial. One PKP tutor in Bogor said, "I find that the teachers have difficulties understanding the concept of action research, even though they have taken the PTK course. I have to help them relearn what action research is. It may be that when they took the PTK tutorial they only learned the theories. They were not given the opportunity to apply the theories into real practice" (Rini Interview, 20 September 2008). Another tutor complained, "I think the module does not cover the deep discussion of the materials."

In the second round of data gathering teachers participating in a PKP tutorial were asked to respond to a written questionnaire. While many teachers (74 percent) reported that the material of the PKP tutorial is interesting to them and the that tutor appeared to have mastered the materials (81 percent) and provided useful guidance in writing the PKP report ( 88 percent), a majority (56 percent) found the PKP module difficult to study while even more (67 percent) of those responding found it difficult to implement what they had learned in their lesson plans. A significant majority (72 percent) also stated that the four semester gap between the first action research tutorial (PTK) and the second action research tutorial (PKP) caused problems. Thus the survey data suggests problems with the content of the PKP manual as well as the designers' original assumption that a four semester gap between the first and second tutorials would enable teachers to apply what they learned in the PTK tutorial before learning to write an action research report in the PKP tutorial.

Along with assessing teachers' perceptions of the PTK module, we wanted to understand what impact their study of the theory of classroom action research in the PTK tutorial had on their conception of its relevance to their teaching. After all, the PTK module and tutorial is intended to enable the teachers to identify problems in their teaching and then overcome these problems through classroom action research. Interviews with teachers enrolled in the PTK tutorial, however, suggest that the action research course may not be accomplishing this objective. Teachers repeatedly asked for more concrete examples of classroom action research. "The module has to be completed with more examples" (Nani Interview, 27 September 2008), said one teacher. Another said "our hope is that we are provided with examples ... examples on problem solving ... since the module only provides steps" (Amah Interview, 4 October 2008). A third complained "there is one example, but the way to make a solution was too direct. The example was not concrete enough. There was no description from the problem in the example" (Ary Interview, 16 August 2009). And these examples, in the teachers' view, should be specifically tailored to the levels they teach. "I want an example concerning teaching in elementary school. In my view it was not justified when the examples were cases from junior or senior high school" (Cacih Interview, 16 August 2009).

Both teachers and tutors also suggested that the action research module should contain more detailed, step-by-step instructions on how to carry out an action research project. One tutor claimed, for instance, "The PTK module does provide steps on how to conduct action research. However, the steps are too general. Teachers need more detailed steps so that they are able to conduct action research in their class" (Dody Interview, 13 September 2008). Another tutor said the module does not provide a sufficiently thorough and detailed discussion of the course materials. The result is that teachers do not feel prepared to conduct action research in their classrooms even after they have completed the classroom action research course.

Another issue that arose in the course of the second cycle of data collection involved the nature of the final examination that is used to determine teachers' grade in the course. Many teachers felt than an objective test was an inappropriate tool to measure learning that ostensibly emphasizes action. "The course is action research, which means action. So why is the final test an objective test? I think it contradicts the nature of the course. Moreover, since we are only tested with an objective test, our tutor seemed to think that we do not need to practice doing action research. We were not asked to conduct action research in the PTK course" (Jumi Interview, 27 September 2008). Another teacher remarked, 
"according to me, the final test doesn't fit with the process of learning. We were supposed to learn by practicing the theory, but when we had the test we were only given objective questions" (Leny Interview, 16 August 2009).

Another problem that came up in interviews with teachers concerned the four semester gap between the PTK and PKP tutorials. Most teachers felt that two years was a very long time to wait. Many forgot what they had learned in the first course by the time they were ready to take the second. "The time between the PTK course and the PKP course is too long. The latter should be delivered right after the PTK course. It's just that I forget..." (Budi Interview, 11 January 2009). Another teacher said "the PTK course is offered in semester six while the PKP is offered in semester ten. It needs two years to implement PTK and it was considered a very long time to wait" (Nita Interview, 16 August 2009). Another suggested "It will be more meaningful if the PTK course is put into practice in the PKP report, but the length of time should be considered" (Tina Interview, 16 August 2009). Teachers clearly do not seem to be practicing classroom action research on their own in the period between the PTK and PKP courses as the course designers originally envisioned.

A final round of interviews was conducted at both research sites. These interviews, again, revealed a number of difficulties teachers are having in learning to conduct classroom action research through the UT tutorials, but they also revealed a generally positive attitude on the part of teachers toward action research. Teachers seem to have considerable difficulty with basic writing as well as organizing their writing in the format of an action research report. One teacher admitted "I have difficulty in composing sentences to make an action research report" (Jumi Interview, 27 September 2008). Another agreed in that "Teachers lack the skills to choose the right words and to compose accurate sentences for a PKP report" (Giman Interview, 16 August 2008). They also reported difficulty in gathering and analyzing data: "It is difficult to search for and record data, do the analysis in every cycle and develop a proposal" (Amah Interview, 4 Oct 2008).

The tutors generally confirm the teachers' reports of their problems with writing generally and writing an action research report specifically. "Teachers are not accustomed to write reports" (Lina Interview, 20 September 2008), one tutor reported. Another said "They lack skills in describing and analyzing research results, not to mention their lack of skills in composing sentences" (Dody Interview, 13 September 2008). Another suggested that "to increase teachers' ability to conduct action research, teachers need to be assigned with writing reports" (Sumartono Interview, 13 September 2008).

Teachers were similarly critical of their tutors' familiarity with the material and their ability to teach it. One teacher complained that "The tutor did not master either PTK or PKP (Budi Interview, 11 January 2009). Another said of her tutor, "The tutor seemed to be a little too textbook, so he failed to provide a realistic picture to us. As teachers, we have a rather heavy load of courses" (Cacih Interview, 16 August 2009). Some teachers seemed to think that the tutors' poor performance directly affected their ability to learn to conduct classroom action research: "If the tutor is capable to present the materials, teachers would learn carefully and diligently" (Tati Interview, 11 January 2009). From the data reported by both teachers and tutors, about each other and themselves, it appears that neither teachers nor tutors are adequately prepared to fully benefit from the two action research courses, even if the modules themselves have problems.

\section{Discussion}

The literature on action research - as the very name suggestsemphasizes action, intervening in a problematic situation in a thoughtful and systematic fashion for the purpose of changing the problematic situation and directing it to a more desirable end (Gilmore, Krantz, and Ramirez 1986; Kemmis and McTaggart 2000, Reason and Bradbury-Huang 2001; Stringer 2007). Ironically, however, there seems to be very little action in the action research tutorials as they were implemented in these two study sites. Teacher-learners are reading about classroom action research. They are reading the theory of classroom action research. But they are not doing classroom action research. Both teacherlearners and tutors recognize this lack of practice as a significant problem that impedes teachers' learning to conduct classroom action research.

This lack of action may be due, in part, to mistaken assumptions about the teacher-learners by the designers of the course. The first course (PTK) seems to assume that teacherlearners simply need to be told how to do classroom action research and they will do so. Moreover, it assumes that teacherlearners already possess key skills necessary to conduct classroom action research: the ability to identify problems in the classroom, the initiative to respond to them, the ability to analyze data, and the writing skills necessary to describe what they have done. Our research suggests, and the teacher-learners and tutors interviewed in these tutorial sites agree, that many teachers lack these basic prerequisite skills.

These problems, moreover, are further complicated by the distance education context. As mentioned above, UT recognizes that learning in such a context requires a fairly high degree of individual initiative, intrinsic motivation, and self-discipline. However, many of the teachers enrolled in these courses are not enrolling because of international but rather external motivation: 
the government requirement that all teachers will have a baccalaureate-level degree by 2015. Their request for more concrete examples is a useful recommendation. However, their insistence on more examples - even to the point of examples tailored to the grade-levels or subject matter of individual teachers - suggests a problem with transferring learning from one context to another. It also suggests a lack of independence, a need to be told what to do that is at odds with the idea of research aimed at figuring out what to do. Thus, the evidence of this study suggests there is a mismatch between what UT's classroom action research tutorials expect of their audience and the needs and abilities of their actual audience.

\section{Conclusion and Recommendations}

Based on the data gathered in all three cycles, it appears that there are a number of problems both with the content and scheduling of the action research courses as well as the abilities both teachers and tutors bring with them to the tutorial. The modules themselves appear to be too theoretical and do not provide adequate scope for tutorial participants to practice what they are learning. They need to be more detailed and explicit in their instructions to teachers and provide concrete examples of classroom action research in a wider variety of classrooms. The use of an objective test to measure learning in the first action research course appears to reinforce the theoretical bias of the module itself, further reducing the likelihood of teachers' having an opportunity to practice what they are learning in the course. And the four semester gap between the first and second action research courses is not being used, as designers intended, to practice action research but is rather another large gap between learning the theory and engaging in the practice of classroom action research that further undermines teachers' ability to carry it out.

As for the teachers and tutors themselves, both seem to lack some of the knowledge and skills presumed in the design of both courses. Teachers appear to lack the skills to critically and systematically analyze problems in their own classrooms, to write or to organize their reflections on their activities at the level assumed in course materials. It also appears that some tutors are themselves either unfamiliar or inexperienced with classroom action research and are thus unprepared to supplement the module with their own knowledge and experience or guide teachers in the practicalities of conducting classroom action research. Both of these issues need to be addressed in the design, content, and staffing of the action research tutorials.

We recommend, therefore, that modules be redesigned to include more explicit exercises as well as more examples of classroom action research projects at various levels as well. Example action research reports should also be included. Both might be offered in the form of video compact disc supplements to the written modules. Tutorial sessions should also provide clear guidelines for conducting action research as well as ample opportunities to practice various aspects of it. A more authentic assessment of teachers' learning in the classroom action research course would be helpful in shifting the emphasis of the course from theory to practice. Finally, both teaches and tutors would also benefit from workshops and other materials that might help them better understand how to teach and learn about classroom action research in a distance education format.

\section{References}

Brown, Beth L. 2002. "Improving Teaching Practice through Action Research." PhD diss., Educational Leadership and Policy Studies, Virginia Polytechnic and State University, Blacksburg, Virginia, USA.

Gilmore, Thomas, Jim Krantz, and Rafael Ramirez. 1986. “Action Based Modes of Inquiry and the Host-Researcher Relationship." Consultation 5 (3): 160-176.

Hanson, Cindy, and Lori Hanson. 2010. "Unpaid Work and Social Policy: Engaging Research with Mothers on Social Assistance." Action Research 9 (2): 179-198.

Kemmis, Stephen, and Robin McTaggart. 2000. Participatory Action Research: Communicative Action and the Public Sphere. In Handbook of Qualitative Research. 2nd ed., ed. Norman K. Denzin and Yvonna S. Lincoln (pp. 559-604). Thousand Oaks, CA: SAGE Publisher.

Mendenhall, Tai, Peter Harper, Heather Stephenson, and G. Santo Haas. 2010. "The SANTA Project (Students Against Nicotine and Tobacco Addition): Using Community-Based Participatory Research to Reduce Smoking in a High-Risk Young Adult Population.” Action Research 9 (2): 199-213.

Ngwerume, Karebor Tuhaise, and Markus Themessl-Huber. 2010. "Using Action Research to Develop a Research Aware Community Pharmacy Team." Action Research 8 (4): 387-406.

Reason, Peter, and Hilary Bradbury-Huang, eds. 2001. The SAGE Handbook of Action Research: Participative Inquiry and Practice. Thousand Oaks, CA: SAGE Publications.

Stringer, Ernest. 2007. Action Research. Thousand Oaks, CA: SAGE Publications.

Indonesia Open University (UT: Universitas Terbuka). 2001. A Journey towards Leading Open and Education Institution. Jakarta: UT. 